Revista Iberoamericana, Vol. LXVIII, Núm. 200, Julio-Septiembre 2002, 807-813

\title{
LEZAMA: ENTRE LA POÉTICA Y LA POESÍA
}

\author{
POR
}

Abel E. Prieto

UNEAC

"Al final su caudal se vuelve circular y comienza a hervir": ${ }^{1}$ el río se convierte en un espejo bullente, en el espejo donde Narciso — aguijoneado— se hundió en un esfuerzo cognoscitivo supremo. Este espejo-río nos lleva de la mano a la poética de Lezama. Una poética que rebasa lo meramente estético, se expande hacia la ética, la filosofía y la historia, y ofrece la chispa de la Utopía, intentando lamer con sus aguas las puertas del Paraíso. Aquel anhelo oscuro por alcanzar una definición para lo indefinible que anima a Narciso en su contemplación del espejo-río, y que aparece luego — sonriendo todavía— en el suave regaño de “Ah, que tú escapes”, se endurece en la prosa ensayística de Lezama para proponernos un sistema que ofrece una visión global — desde la poesía— del anverso y del reverso del mundo.

Si bien toda la obra de Lezama está cruzada obstinadamente por la aspiración de dialogar con la poesía, de fijar por unos segundos a la interlocutora huidiza y proteica, el lector advierte bifurcaciones inquietantes. En su labor ensayística, ese diálogo se articula y crece a través de los años en el esfuerzo por fundar un sistema poético que dé respuestas tranquilizadoras a los pequeños y a los grandes enigmas; en el verso lezamiano, junto a un grupo de poemas ya clásicos, muy sobados por la crítica justamente porque se derivan de aquellas teorizaciones, crece la batalla entre el poeta (explorador incansable, criatura maldita, inconforme y feroz) y su propia poética, por flexible, renovadora y antidogmática que parezca.

Si el fundador del sistema poético avanzó, paso a paso, hacia un imán donde estuvieran todas las soluciones, el poeta se fue quedando solo con el fragmento hay un desfase entre el camino seguido por la reflexión de Lezama, cada vez más coherente, sistemática y abarcadora, cada vez más afincada en una mirada integral sobre el mundo, y el desarrollo de su poesía, donde se va imponiendo una pupila fraccionada y un mecanismo asociativo más y más libre (en el ciclo que va de Aventuras sigilosas hasta Dador), y la revelación de un ámbito personal, donde ese fraccionamiento permite la entrada en el discurso poético lezamiano de confidencias, sentimentalismos e incertidumbres que el sistema no puede prever: Fragmentos a su imán.

\footnotetext{
${ }^{1}$ José Lezama Lima, “Confluencias”, La cantidad hechizada, en Obras completas (México: Aguilar, 1977) 1228. Todas las citas de los ensayos de Lezama se hacen por esta edición.
} 
Sin embargo, tanto la elaboración teórica como el rastreo ciego, sin aprioris, del hacedor de poesía que palpa en la oscuridad, se basan en un mecanismo central en Lezama, que brota naturalmente de su condición definitoria de poeta: la búsqueda de enlaces ocultos entre elementos separados por abismos de tiempo, espacio o sentido.

El hallazgo de estas conexiones inesperadas, que subvierten las estructuras de un pensamiento racionalista chato y presentan una nueva relación causa-efecto, también apunta hacia la revelación de una armonía universal encubierta, vedada al hombre por la maldición de lo sucesivo y la lluvia de fragmentos carentes de imantación. Es "el rayo que une las dos refracciones de las dos cámaras distintas” y que logra disolver así los “extraños mundos saturninos”, desmembrados, que angustian al hombre. ${ }^{2} \mathrm{Al}$ establecerse el enlace lezamiano, queda abolida la jerarquización habitual; ya entre los elementos conectados no existe la subordinación del derivado al antecedente: tienen el mismo valor. Todos los elementos enlazados aportan, en el circuito mágico que se cierra, una carga germinativa similar. Por otra parte,

La claridad de un hecho puede ser la claridad de otro, cuya semejanza no es equivalente, que permanecía a oscuras, pero la iluminación o sentido adquirido por el primer hecho, al crear otra realidad, sirve de iluminación o sentido al otro hecho, no semejante. ${ }^{3}$

Aproximar un hecho, una "entidad”, un objeto, a la luz emanada por otro, que arde en el espacio abierto por una nueva causalidad, es fuente incalculable de conocimiento y nos permite entrever una realidad esencial superior. No olvidemos que,

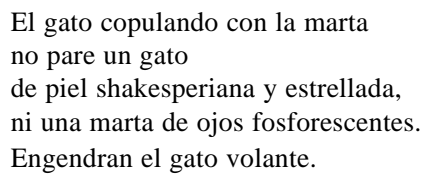

En general, todos los procedimientos creativos de Lezama se colocan en el ámbito de una causalidad diferente, donde son posibles las más inesperadas conexiones y donde puede ser engendrado el gato volante. La vivencia oblicua -momento culminante de la nueva causalidad, donde un hecho genera otro sin que entre ellos exista ninguna relación lógica de causa y efecto- es bosquejada desde 1948, como ingrediente para fundar ese espacio, ese "reino de la absoluta libertad". ${ }^{4}$ Allí la vertical de la causa ya no cae en ángulo recto sobre la horizontal del efecto: en el espacio poético los fenómenos se cortan oblicuamente, creando una textura geométrica sólo en apariencias caótica: realmente de urdimbre mucho más cerrada y perfecta.

Cuando Lezama propone la verdad poética, no pretende hacer pedazos la imagen racional del mundo; sino, por el contrario, dar un sentido al caos, "trazar un continuo en

\footnotetext{
${ }^{2}$ Lezama Lima, “La dignidad de la poesía”, Tratados en la Habana, 769.

${ }^{3}$ Lezama Lima, “La imagen histórica”. La cantidad, 849.

${ }^{4}$ Lezama Lima, “Las imágenes posibles”, Analecta del reloj, 159.
} 
aquel mundo que surgió como la discontinuidad mayor". ${ }^{5}$ Apuntando hacia esa coherencia invisible, hacia esa isla utópica personal, se aparta de los francotiradores que aspiran a destrozar la estabilidad confortable de la razón burguesa, para instalar — arrasados todos los valores - el demonio del absurdo: más bien construye otro sistema racional, considerando al existente incapaz de resolver los misterios de un modo desintegrado. Sugiere un sistema para alcanzar la concordancia universal, basado — esta vez - en "una razón poética, en un sentido derivado de las asociaciones momentáneas”; ${ }^{6}$ basado en el razonamiento inocente, pletórico de fe, capaz de asimilar con naturalidad el milagro del cristianismo primitivo.

En la base del sistema está la imagen, que se alza como la única vía del hombre para relacionarse con el universo objetivo y con el territorio secreto de lo invisible; del mismo modo que sólo ella puede mostrar la intersección entre esos dos ámbitos y desmentir cualquier concepción dualista. La imagen, instrumento cognoscitivo por excelencia, compañera del hombre en todas sus aventuras vitales, encuentra su lugar idóneo en la poesía: allí se abren sus oportunidades más ricas; allí su apetito de conocer consigue los frutos mejores; allí cumple sus múltiples milagros de manera más cómoda y transparente, porque la poesía es el reino propio del milagro.

La imagen viene a ser la intermediaria entre el poeta y la sustancia poética: asegura el fugaz, relampagueante vínculo con esa entidad siempre fluyente; logra aquellos minutos inapreciables en que el río se hace espejo en una cristalización instantánea; construye, en el prodigio del poema, la "fotografía de la respiración”, 7 y nos entrega una estampa congelada del movimiento poético — que repite el movimiento mismo de lo real. Y es que la sustancia poética lezamiana participa de la dinámica inagotable de la vida: bulle zigzagueando en el espacio y en el tiempo, despojada de todo lo accesorio, como si quisiera reflejar lo esencial de los desplazamientos vitales.

El afán por dialogar con la sustancia poética puede leerse como un impulso cognoscitivo hacia la realidad y hacia la vida, y la construcción de ese espejo-río, de esa "sustancia tan real, y tan devoradora", ${ }^{8}$ como una sintética representación de los enigmas objetivos que rodean al hombre y de su propio transcurrir a través de los mismos.

La sustancia poética ofrece una permanente resistencia a ser atrapada en el cuerpo estrecho del poema, necesariamente limitado por una forma y por su condición de estado y de continuo. Siendo la poesía “instante y discontinuidad”, flujo irregular, materia informe que escapa de las coordenadas temporales y espaciales, su presencia en el estado de reposo y en la estructura formal, palpable, del poema, constituye por definición, un imposible. El contacto entre el poema y la poesía, la aspiración a que la poesía habite el cuerpo del poema - a que el instante se haga estado; lo discontinuo, continuo-, se fundamenta en la solución de los antagonismos centrales que se dan en la relación arterealidad: aquella traición, al parecer inevitable, que Borges sintetizó a su modo — tan

\footnotetext{
${ }^{5}$ Lezama Lima, Analecta, 165.

${ }^{6}$ Lezama Lima, "Prosa de circunstancia para Mallarmé”, Analecta, 265.

${ }^{7}$ Lezama Lima, “Del aprovechamiento poético”, Analecta, 254.

${ }^{8}$ Son palabras de Lezama en carta citada por Cintio Vitier en "La poesía de José Lezama Líma y el intento de una teología insular”, en Recopilación de textos sobre José Lezama Lima (La Habana: Casa de las Américas, 1970) 73.
} 
limpiamente - en la persecución literaria de "El otro tigre”, desvela a Lezama cuando medita sobre el icárico proyecto de fijar la sustancia poética por medio de esos objetos clavados en el papel, mensurables y quietos. La exploración de Lezama, sin embargo, no se resuelve en el desaliento del cazador de Borges: en el reverso de la sustancia poética hay una continuidad esencial, el fantasma de la unidad de lo real —que tantos accidentes y fragmentos dispersos nos impiden percibir—: "Discontinuidad aparente ... Continuidad de esencias". ${ }^{9}$ Esta potencialidad cognocitiva del acto poético, al revelar los enlaces ocultos que dan coherencia a una realidad dislocada e incomprensible, deviene potencialidad utópica y responde a esa angustiosa pérdida de toda noción de unidad que atormenta al arte contemporáneo.

El sistema poético lezamiano se fundamenta en varias parejas de contrarios, que oponen incesantemente continuidad-discontinuidad, estatismo-movimiento, eternidadtemporalidad, ser-devenir, aislamiento-reconstrucción. ${ }^{10}$ La poesía y la propia vida viajan continuamente de un polo a otro. La solución (si es que Lezama pensó en términos de solución) no está en afincarse en uno de los extremos de la pareja; sino en una zona intermedia, que mantiene el movimiento y no aniquila ninguna de las circunstancias en oposición: allí donde el fragmento participa en la unidad, sin perder por ello — aunque ya imantado para siempre - su digna condición de fragmento: allí donde recibimos la "imagen de la eternidad” como "efímeros dichosos”, ${ }^{11}$ allí donde podemos fijar la corriente de la poesía, sin que el espejo niegue esencialmente al río. Sin embargo, la fragata que protagoniza uno de los mejores poemas de Fragmentos a su imán, cuando encuentra un "círculo / azul inalterable con bordes amarillos / en el lente cuadriculado de un prismático", es un efímero equilibrio; luego-interminablemente-va a comenzar "de nuevo su combate sin saciarse”.

La solución dinámica traicionada por la práctica de la poesía, surge otra vez cuando examina la fachada barroca de una catedral peruana y descubre, en "el esfuerzo por alcanzar una forma unitiva”, entre tan diversos elementos ornamentales, una tensión. Es —nos dice Lezama — como si "el señor barroco quisiera poner un poco de orden pero sin rechazo, una imposible victoria donde todos los vencidos pudieran mantener las exigencias de su orgullo y de su despilfarro". ${ }^{12}$ Es la misma tensión que rige la batalla entre las frases contrarias de Aristóteles (que exalta el reposo) y la de Pascal (que exalta el movimiento), trazadas en los pizarrones mágicos, donde se polarizan, magnetizadas, arremolinadas, sin que haya nunca vencedor ni vencido. ${ }^{13}$ Es — también — la tirantez de un discurso poético que atrapa primero "las acumulaciones del sentido". ${ }^{14}$

En ese flujo y reflujo descubrimos, además, el viaje continuo que va del individuo al arquetipo, y regresa siempre - lavado por el sumergimiento en las aguas de lo supraindividual — al hombre-fragmento, renovado, aunque manteniendo el patrimonio de

\footnotetext{
${ }^{9}$ Lezama Lima, “X y XX”, Analecta, 147.

${ }^{10}$ Véase el excelente ensayo de Rubén Ríos Avila, “La imagen como sistema”, Coloquio internacional sobre José Lezama Lima: poesía (Madrid: Editorial Fundamentos, 1984).

${ }^{11}$ Lezama Lima, “Confluencias”, La cantidad, 1228.

${ }^{12}$ Lezama Lima, “La curiosidad barroca”, La expresión americana, 304-305.

${ }^{13}$ Lezama Lima, “Introducción a un sistema poético”, Tratados, 395.

${ }^{14}$ Lezama Lima, Tratados, 397.
} 
su orgullo y de sus despilfarros: es Garcilaso, en el momento de su muerte, penetrando en su ser histórico, "integrando la persona contradictoria saturadora del arquetipo categorial”"15 y ofreciendo, también en este caso, la síntesis que suprime todo dualismo; o Simón Rodríguez, que se acerca y se aleja del diálogo con el paisaje — forma de comunión colectiva "por el que este espíritu muy cargado, por la que este individualista de desesperada última instancia, pudiera soltar el ascua, deshacerse de la maldición”. ${ }^{16}$ En la inclinación de Lezama (y de todo Orígenes) hacia el arquetipo, hay — como en el señor barroco - la intención de poner orden pero sin rechazo; el respeto hacia la delicada dialéctica que debe reinar en la configuración del personaje-arquetipo, para no rematar en él torpemente las larvas aprovechables de lo individual.

Edificada sobre tantas y tan variadas antinomias, la poética de Lezama es, como vemos, enemiga de los dualismos, de los esquemas que obstaculizan la comprensión de un mundo donde se entrelazan todos los hilos; donde se confunden fauna y flora, naturaleza y sobrenaturaleza; donde reina un sinfín de nexos invisibles que garantizan la armonía universal. Desde su temprano ensayo “El secreto de Garcilaso” (1937), Lezama se pronuncia contra los dualismos arte culto-arte popular, arte-vida y hasta contra la tajante oposición Medioevo-Renacimiento: todos ellos están resueltos en la figura de Garcilaso, como equilibrada síntesis. Para comprender el proceso literario, son nocivos los esquemas que oponen a Góngora y San Juan y poesía hermética-poesía clara. Sólo “los acogidos ala tranquila infancia de una escisión poética, los que no han podido sobrepasar una comprensión primaria, elemental, de la poesía, pueden sentirse cómodos en medio de esas clasificaciones profesorales. ${ }^{17}$

Hay que derribar las paredes de cristal o de piedra, las más sutiles y las más burdas, para encontrar las confluencias. Todos los dualismos nos empobrecen y nos alejan de la utopía. La poesía, incluso, está capacitada para disolver el dualismo esencial; puede “destruir la antítesis realidad e irrealidad, formando una esperada médula de saúco". ${ }^{18} \mathrm{La}$ poesía es el ámbito idóneo para las correspondencias, donde no existen ya los tabiques levantados por el racionalismo burgués dieciochesco, que en su resaca irónica nos devuelve los laberintos culturales de Borges. Aquella diosa Razón, que pretendía mostrarnos la imagen de un mundo explicable y armonioso, degeneró (por su raíz clasista; gracias a la conocida fábula de una clase que se acostó revolucionaria y despertó aferrada a un poder que defendería a sangre y fuego) en la parcelación positivista, en el fraccionamiento definitivo del mundo, y en las caricaturas que de ella haría — por poner un ejemplo del ámbito hispanoamericano - un Borges.

La angustia de un intelecto desvalido ante la crisis del racionalismo burgués, debe desaparecer cuando se traspasa el umbral del ámbito poético lezamiano: allí rigen ciertas leyes; pero son diferentes y tienen — como la ciudad ideal— “la medida del hombre”, están concebidas para humanizar el arte y la vida, que son inseparables. Hay en este reino otra verdad, otro sentido, y las nociones cardinales de tiempo y espacio han cambiado: el

\footnotetext{
${ }^{15}$ Lezama Lima, "El secreto de Garcilaso”, Analecta, 35.

${ }^{16}$ Lezama Lima, "El romanticismo y el hecho americano”, La expresión, 337.

${ }^{17}$ Lezama Lima, "Sierpe de Don Luis de Góngora”, Analecta, 186.

${ }^{18}$ Lezama Lima, “Cortárar y el comienzo de la otra novela”, La cantidad, 1199.
} 
tiempo se endurece, se niega, resiste su propia condición; mientras que el espacio se aligera, propicio, evitando asfixiar a sus habitantes con una imposición material excesiva. ${ }^{19}$ Tiempo y espacio favorecen así la creación del hombre en un medio amable; donde aquélla puede alcanzar una especial sobreabundancia, una riqueza barroca que acumula posibilidades para que el sentido poético cristalice; donde se abre la promesa de la posibilidad infinita, que es — finalmente — la única opción que puede acercar las aguas del río al Paraíso.

Aunque el sistema poético de Lezama reconoce en el tiempo a un enemigo difícil, persistente, capaz de roer la base de todas las conquistas humanas, no se empeña en negarlo. La poesía —el arte- debe reelaborar el tiempo, digerirlo, cuando ya esté segura en "la otra extraña ribera de su pausa", ${ }^{20}$ cuando se haya establecido en su propio castillo resistente. Dentro de esas murallas, la temporalidad se expresa de otro modo: Arístides Fernández, por ejemplo, hizo la mayor parte de su obra en un "súbito temporal”21 de gran fecundidad; Portocarrero, con un símbolo personal, "logra un tiempo sin antecedentes ni consecuentes", 22 Zequeira y Arango llega a ofrecernos un poema situado "en un tiempo meramente poético, liberado de toda circunstancia cronológica”. ${ }^{23}$ Ese tiempo distinto es una victoria sobre el tiempo devorador; es el fruto de la siembra del mulo en el abismo y de su resistencia.

En cuanto al espacio propio de lo poético, no sólo es capaz de configurarse en el texto; también en el mundo objetivo, algunas peculiaridades con fluencias de elementos diversos suelen fundar una zona de misterio, una zona de poesía: son las llamadas coordenadas poéticas. "Una mágica, imponderable combinatoria especial, tocada apenas ... por una temporalidad reverente llegada como un halo" puede crear una situación poética, absolutamente extraliteraria. ${ }^{24}$ En el fundamento mismo de sus eras imaginarias están tales "situaciones excepcionales, que ... logran penetrar en el invisible poético"; ${ }^{25}$ como están en la base de su rechazo — genuino, ajeno a cualquier pose intelectualista ante el viejo problema - del dualismo arte-vida. En Lezama hay una raigal continuidad entre vida y creación: la búsqueda de la poesía no termina en el territorio de las palabras; se extiende a toda trayectoria vital del poeta, a sus actos, a su presencia — como testigo o protagonista - en cada una de las particulares combinaciones de la realidad; abarca todo su vínculo con el mundo, con la historia, con las visitas de los sueños y con las apariciones de la vigilia. Y siempre, siempre, las coordenadas poéticas necesitarán de una “temporalidad reverente”, distinta, respetuosa, que permita espesar la atmósfera en la zona de misterio, que no estorbe el nacimiento del espejo en ese momento circular del río.

En otras ocasiones, este espacio poético adquiere una dimensión metafísica: Lezama describe un doble movimiento — de ascenso hacia Dios y descenso a los infiernos-y le

\footnotetext{
${ }^{19}$ Lezama Lima, “Las imágenes posibles”, Analecta, 170.

${ }^{20}$ Lezama Lima, “Introducción”, 403.

${ }^{21}$ Lezama Lima, “Arístides Fernández”, La cantidad, 1121.

${ }^{22}$ Lezama Lima, “Homenaje a René Portocarrero”, La cantidad, 1142.

${ }^{23}$ Lezama Lima, "Prólogo a una antología”, La cantidad, 1010.

${ }^{24}$ Lezama Lima, “Introducción”, 399.

${ }^{25}$ Lezama Lima, “A partir de la poesía”, La cantidad, 825.
} 
otorga ala poesía una pausa intermedia entre las dos corrientes, que le permite el privilegio de una suerte de objetividad, de "retiramiento", y resulta idónea para encontrar un sentido e hilvanar el conocimiento órfico con el conocimiento "de salvación”. ${ }^{26} \mathrm{Y}$ en otro momento sentencia: "la poesía tiene que empatar o zurcir el espacio de la caída", ${ }^{27}$ definiendo — con una metáfora insustituible— la misión trascendente de su poética. En la criatura expulsada del Paraíso ha quedado, gravitando, el vacío de esa naturaleza perdida; que pudiera llenarse con la sobrenaturaleza, formada por la intervención de la imagen: Lezama coloca de este modo "frente al pesimismo de la naturaleza perdida, la invencible alegría en el hombre de la imagen reconstruida”. ${ }^{28}$

Esa invencible alegría y esa imagen reconstruida que la poética de Lezama nos ofrece como ganancia trascendente de su madurez, contrasta con los minutos de caos, las dudas, los temblores, que va descubriendo en la práctica de la poesía el autor de Fragmentos $a$ su imán: la poética del sistema y su retórica aparecen minadas aquí por una exploración que se relaciona con el esquema romántico poesía-expresión del sentimiento y —en menor medida - con el esquema surrealista poesía-expresión del subconciente, esencialmente incompatibles con los principios básicos de la teorización lezamiana, y es que el sistema poético carecía de flexibilidad para acomodar en sus habitaciones todo el proceso de conmoción espiritual que estaba sufriendo su creador. Las fisuras del sistema ya no podían ocultarse, y Lezama — con honestidad de poeta verdadero- no las ocultó.

Fragmentos a su imán no hubiera podido fundar un movimiento, como lo hizo Enemigo rumor. Le falta el sentido integrador, esa imagen de mundo sin intersticios. Allí, en medio de la retórica del sistema, asoma una poesía distinta, insegura por momentos, que alarga las manos en la tiniebla como queriendo que alguien las apriete, ${ }^{29}$ desmintiendo lenguajes y recursos esquematizados ya bendecidos por el éxito.

Lezama, entre la poética y la poesía, viajando hacia el imán (hacia la armonía invisible y el vencimiento del tiempo y de la nada) o hacia el fragmento (hacia la intimidad de un yo poético bruscamente personal, necesitado de una nueva voz), deja el testimonio de sus contradicciones como un ejemplo de valentía intelectual. Corresponde, como debe ser, a los exégetas, traicionar ese ejemplo, batirlo todo, y ofrecer una hermosa estampa conciliatoria.

Volumen LVII

Enero-Marzo 1991

Número 154

\footnotetext{
${ }^{26}$ Lezama Lima, “Introducción”, 403-405.

${ }^{27}$ Lezama Lima, Tratados, 762.

${ }^{28}$ Lezama Lima, La cantidad, 1213.

${ }^{29}$ Del poema "Los dioses", Fragmentos a su imán. Sobre esto puede verse la periodización que propongo en "Poesía póstuma de José Lezama Lima”, Casa de las Américas, XIX, 112, enerofebrero 1979, y en "Fragmentos a su imán (notas sobre la poesía póstuma de Lezama)”, en Coloquio.
} 